\title{
REDUCTION OF WOOD BASIC DENSITY IN DECAYED GREY ALDER STEMS
}

Jānis LIEPIN̦Š, Latvian State Forest Research Institute Silava, Rigas street 111, Salaspils, Latvia, janis.liepins@silava.lv (corresponding author)

Alise BLEIVE, Latvian State Forest Research Institute Silava, Rigas street 111, Salaspils, Latvia, alise.bleive@ silava.1v

Andis LAZDIN̦Š, Latvian State Forest Research Institute Silava, Rigas street 111, Salaspils, Latvia, andis.lazdins@ silava.lv Kaspars LIEPIN̦Š, Latvian State Forest Research Institute Silava, Rigas street 111, Salaspils, Latvia, kaspars.liepins@ silava.lv

This pilot study aims to estimate the impact of the internal stem decay on wood basic density in grey alder stems. Accurate estimates of stem biomass are crucial in reducing the uncertainty in the estimation of forest stand biomass. The density data were obtained from 21 decayed trees and from 15 healthy trees as reference sampled in five forest stands in Latvia. In total, the densities of 401 intact wood, 212 discoloured wood and 117 spongy rot specimens were measured obtained from the cross-cut discs of sampled trees. The Kruskal Wallis test was used to determine the statistically significant differences between mean values of intact wood, discoloured wood and spongy rot basic density. Our analysis revealed that mean basic density of intact wood differed significantly $(p<0.01)$ from the mean values of discoloured wood $-361.3 \mathrm{~kg} \mathrm{~m}^{-3}$ and spongy rot $-240.9 \mathrm{~kg} \mathrm{~m}^{-3}$ suggesting that decrease in wood density due to the internal decay must be taken into account for the stem biomass calculations. Our findings indicate that spongy rot incidence varied strongly between individual forest stands, from $2.4 \%-80.9 \%$. Other studies have confirmed that not only the density but also the carbon content of wood varies by its decomposition process.

Keywords: wood decay, carbon stock, Alnus incana, stemwood density

\section{INTRODUCTION}

Forests play an important role in sequestering carbon dioxide from the atmosphere and the mechanisms that are affecting the carbon sink in forest ecosystem are diverse (Brown, 2002; Pan et al., 2011). Assessing carbon sequestered in forests relies on the quantification of above- and belowground biomass assuming that a certain fraction of that is carbon (Neumann et al., 2016). The use of allometric equations on National forest inventories (NFI) data for estimating tree biomass has become the standard approach to estimate the forest biomass and carbon stock in sample plots and then recalculating it at a national scale. Forest management and policy decisions aimed to increase the carbon accumulation depend on reliable estimates of carbon in forest ecosystems.

Allometric biomass equations have commonly been developed sampling decay-free and healthy trees ignoring the presence of rotten wood in forest area. These assumptions might lead to an overestimation of stem biomass and consequently - carbon stock, given the occurrence of internal stem decay. Wood decay results to the emission of stored carbon back into the atmosphere. This is an important but poorly understood carbon loss in our forests. Wood decay is a biological process that occurs in stem or tree roots and is common in all forests and is most widespread in the lower part of mature trees. While recent studies in hemiboreal forests (Köster et al., 2015; Šenhofa et al., 2020) have studied the decay types and wood basic density of coarse woody debris and its contribution as a carbon source in forests, the basic density of internal decay in growing grey alders has not been sufficiently studied so far.

Grey alder is a fast-growing pioneer species and native to most of central Europe and in all Northern European countries (Houston Durrant, Rigo, \& Caudullo, 2016) and are especially widespread in all Baltic countries (Rytter et al., 2016). According to national forest inventory (NFI) data, grey alder forest stands cover $10.2 \%$ of the total forest area in Latvia (CSB, 2019) and the proportion of grey alder stands is still increasing. Destructive sampling has been used in the previous study to assess the incidence, extent and yield loss of internal decay for grey alder stands in Latvia (Arhipova et al., 2011) concluding that decay is important factor determining biomass production and wood quality in alder stands. According to the study $18 \%$ of grey alder stems in Latvian forests are damaged by internal stem decay and the volume of decay-degraded wood in grey alder stands in Latvia is up to $60 \mathrm{~m}^{3} \mathrm{ha}^{-1}$ at the age of 60-65 years. In Finland observed proportion of internal stem decay in alder stands is even higher, 36\%, 29\% and 33\% for trees under 40 years, 41 to 60 years and over 60 years of age, respectively (Kärki, Maltamo, \& Eerikäinen, 2000).

The aim of this study is to estimate the impact of the internal stem decay on wood basic density in grey alder stems. Density data are needed to determine the decayed stem biomass to substitute the density of intact wood currently used in

Copyright (C) 2021 The Authors. Published by Vytautas Magnus University. This is an open-access article distributed under the terms of the Creative Commons Attribution License (CC BY 4.0), which permits unrestricted use, distribution, and reproduction in any medium, provided the original author and source are credited. 
calculations of carbon content with the data reflecting the actual density of wood taking into account the proportion of stemwood decay.

\section{MATERIALS AND METHODS}

The research is designed as a pilot study to develop a methodology for evaluation of the impact of the stem rot on the forest stand biomass and carbon stocks for matured grey alder forest stands and then applying the developed methodology on a larger scale and to other tree species. In the study, intact wood and two types of decay were distinguished samples of tree stems for basic density analysis: (1) discoloured wood without or with slightly changed mechanical properties and (2) decomposed wood squeezable between two fingers "spongy rot". Five mature and naturally regenerated grey alder forest stands located in Latvia, were included in the study (Table 1). Only forest stands dominated by grey alder were selected, establishing temporary $500 \mathrm{~m}^{2}$ circular plots within each to assess the proportion of decayed stems. To investigate the health status, after a preliminary visual inspection, the tree stems were drilled horizontally at stump level by the Rinntech RESISTOGRAPH® R650. Three healthy and one to five rotten trees were felled in a stand representing the height range of the trees.

Table 1 Forests stands of grey alder investigated

\begin{tabular}{cccccccc}
\hline Stand Nr. & DBHg, cm & $\mathrm{H}_{\mathrm{g}}, \mathrm{m}$ & $\begin{array}{c}\text { Number of trees } \\
\mathrm{ha}^{-1}\end{array}$ & ${\mathrm{G}\left(\mathrm{m}^{2} \mathrm{ha}^{-1}\right)}$ & Age (year) & $\begin{array}{c}\text { Stand volume, } \mathrm{m}^{3} \\
\text { ha }^{-1}\end{array}$ & $\begin{array}{c}\text { Decayed trees } \\
\text { containing } \\
\text { spongy rot, } \%\end{array}$ \\
\hline 1 & 20.9 & 23.7 & 580 & 19.7 & 54 & 212.0 & 27.6 \\
2 & 20.1 & 24.4 & 1240 & 39.2 & 40 & 437.9 & 17.7 \\
3 & 31.0 & 24.2 & 420 & 31.7 & 70 & 341.9 & 80.9 \\
4 & 21.8 & 21.3 & 960 & 35.8 & 55 & 348.2 & 23 \\
5 & 20.7 & 21.7 & 820 & 27.6 & 37 & 274.9 & 2.4 \\
\hline
\end{tabular}

Notes: $\mathrm{DBH}_{\mathrm{g}}=$ basal area-weighted average diameter at breast height; $\mathrm{H}_{\mathrm{g}}=$ basal area-weighted average tree height; $\mathrm{G}=\mathrm{stand}$ basal area.

The tree stems were cross-cut into $1 \mathrm{~m}$ sections starting from the stump height after tree felling to measure the extent of the decay within the stem. Cross-cutting distances of $2 \mathrm{~m}$ were applied for healthy trees. To obtain intact and decayed wood samples, stem discs were cut off at the beginning of each stem section and were also collected at $1.3 \mathrm{~m}$. Decayed wood samples were collected from all cross-sectional discs in which spongy rot or discoloration was found. Healthy stem cross-section discs were used to estimate the decrease in basic density due to internal decay at representative tree heights. As a result, 15 visually healthy and 21 decayed trees were sampled (Table 2) and 295 sample discs were collected.

Table 2 Characteristics of the grey alder sample trees

\begin{tabular}{|c|c|c|c|c|c|}
\hline & $\mathrm{DBH}, \mathrm{cm}$ & Height, $m$ & Tree age, years & Spongy rot length, $\mathrm{m}$ & Decay length, $m$ \\
\hline \multicolumn{6}{|c|}{ Decayed tree stems $(\mathrm{N}=21)$} \\
\hline Mean & 20.9 & 21.9 & & 1.5 & 12.7 \\
\hline Min & 14 & 18.5 & & 0.5 & 4.1 \\
\hline Max & 28.5 & 26 & & 5.5 & 18.2 \\
\hline \multicolumn{6}{|c|}{ Healthy tree stems $(\mathrm{N}=15)$} \\
\hline Mean & 21.7 & 22.8 & 46.7 & & \\
\hline Min & 15.3 & 21.1 & 30 & & \\
\hline $\operatorname{Max}$ & 30.6 & 25.6 & 64 & & \\
\hline
\end{tabular}

The wood specimens for the density determination prepared from the stem discs correspond to the scheme presented in Figure 1. Each specimen width from centre of the stem disc to bark was defined as $2 \mathrm{~cm}$. The number of examined specimens depended on the radius of hearth-rot in each sample disc. All the specimens were saturated (by immersion in water) for $24 \mathrm{~h}$ before the density measurements were conducted. The density of specimens was measured using laboratory scales equipped with density determination software and set (Precisa, Part no: 350-8556). The soft paper was used to drain excess water from the wood specimens before each measurement. The specimens were dried in the oven at $103-105^{\circ} \mathrm{C}$ at least 5 days until a constant weight was achieved for the calculation of basic density. Immediately after specimens were removed from the drying oven the dry weight was determined. Only specimens without obvious wood defects (for example knots) were chosen for analyses. The densities of 401 intact wood, 212 discoloured wood and 117 spongy rot specimens were analysed from the sampled grey alders. 

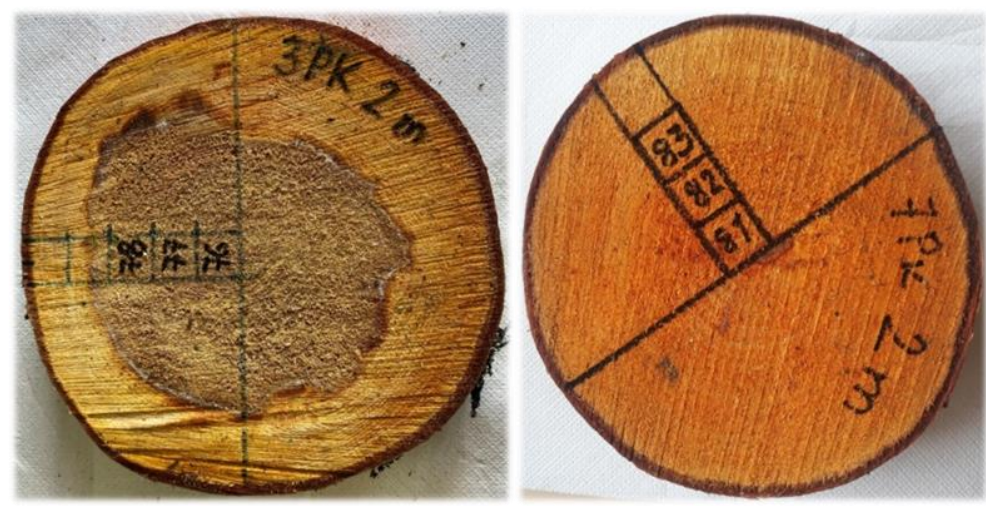

Figure 1. Location of the basic density specimens within the decayed (left) and intact (right) sample discs.

Normality of data distribution was tested with Shapiro-Wilk test, which approved that all tested groups (intact wood, discoloured wood and spongy rot) follow normal distribution. The Levene test rejects the hypothesis that the group variances are equal. Because ANOVA is not robust to this violation, we used nonparametric Kruskal Wallis test to determine if there are statistically significant differences between mean values of intact wood, discoloured wood and spongy rot basic density.

\section{RESULTS AND DISCUSSION}

The existing studies approves the relatively wide distribution of stem decay within grey alder stands indicating that high proportion of infected wood is reducing the value of harvested roundwood. However, the proportion of decayed wood is significantly influencing the amount of carbon captured within the wood biomass, since the scale of the potential overestimate can be notable. The common approach in calculation of stem biomass for carbon accounting is to multiply the volume by basic density (Cienciala et al., 2006; Liepiņš, Liepin̄š, \& Lazdiņš, 2021; Repola, 2009). The mean wood basic density obtained for intact wood is $375.7 \mathrm{~kg} \mathrm{~m}^{-3}$ in our study which is slightly more than reported in similar studies. In Finland, Hakkila (1971) and in Sweden, Johansson (2005) reported a mean basic density for grey alder stems of 360.5 $\mathrm{kg} \mathrm{m}^{-3}$ and $359 \mathrm{~kg} \mathrm{~m}^{-3}$, respectively. However, when comparing these values, it should be kept in mind that the mean density of intact wood in this study was measured only in the middle of the stem and only for matured trees. Owing to the large variation within and between tree stems, mean density values are difficult to compare between different studies (Saranpää, 2003). It has been observed that the highest density of young alders occurs in the upper part of the stem (Aosaar et al., 2011) which means that the sampling methodology greatly affecting the mean density values.

The mean basic density of intact wood obtained in our study differed significantly $(p<0.01)$ from the mean density of discoloured wood $-361.3 \mathrm{~kg} \mathrm{~m}^{-3}$ and spongy rot $-240.9 \mathrm{~kg} \mathrm{~m}^{-3}$ (Figure 3 ). There is a strong evidence that basic density varies depending on wood decay intensity. The decrease in density of discoloured wood is $3.8 \%$ on average, in contrast to the spongy rot, for which the average density has decreased by $35.9 \%$ compared to intact wood. Our results are in line with the general pattern observed in other studies in which wood density was strongly affected by the decay class. However, the decrease in basic density due to the internal stem rot has not been previously studied. In the study of the coarse woody debris in Estonia was concluded that the basic density decreases from $426.9 \mathrm{~kg} \mathrm{~m}^{-3}$ for recently died stems to $124.8 \mathrm{~kg} \mathrm{~m}^{-3}$ for almost decomposed grey alder stems (Köster et al., 2015). The results obtained in Lithuanian study showed that the mean basic density decreased from $400 \mathrm{~kg} \mathrm{~m}^{-3}$ at the beginning of the decomposition processes to $110 \mathrm{~kg}$ $\mathrm{m}^{-3}$ in almost decomposed grey alder wood (Stakenas et al., 2020). In our study, the lowest basic density of a spongy rot wood sample was $71.4 \mathrm{~kg} \mathrm{~m}^{-3}$. This wood sample was obtained on the border of a hollow, where wood was completely degraded within the centre of the decay column, that was found in 4 trees in the oldest (70 years) forest stand.

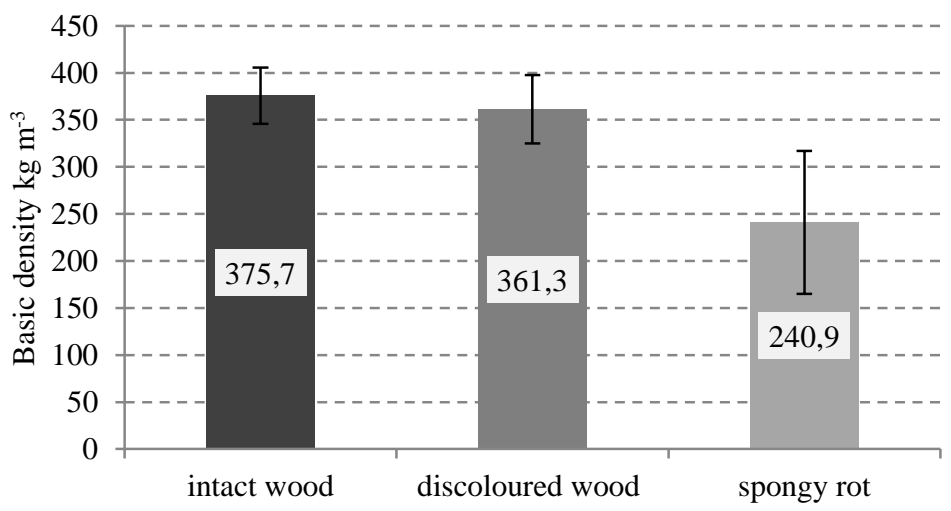

Figure 3. Mean basic density values for intact wood and two types of decay. Error bars represent one standard deviation of uncertainty. 
We found that using resistance drill it is possible to detect only the incidence of spongy rot in trees. By drilling all the trees in the previously established sample plots, it was concluded that spongy rot incidence varied strongly between individual sites, from $2.4 \%-80.9 \%$, and was $30.3 \%$ on average (Table 1). Previous research in Latvia has concluded that the incidence of decayed grey alder stumps on clearfelled sites varied from $1 \%-54 \%$ and a weak positive correlation was observed between the age of the clearfelled stand and decay frequency (Arhipova et al., 2011). Despite high variation in the incidence of spongy rot within individual forest stands, its mean length was found to be only $1.5 \mathrm{~m}$ which is much less compared to the total decay length $(12.7 \mathrm{~m})$ in standing trees (Table 2).

Realizing the importance of stem biomass in the forest carbon cycle, accurate biomass quantifying methods in decayed tree stems are crucial for estimating carbon exchange in the forest areas. However, there still remain several sources of bias for estimation of carbon content within decayed wood. Most of carbon estimation guidelines utilize a default wood carbon content value of $50 \%$, but analysing the global database of dead wood carbon concentration in trees, confirmed that not only the basic density but also carbon content varying significantly from default $50 \%$ value depending on decay classes (Martin et al., 2021). In the continuation of this study, we will analyse the changes of carbon content within the wood affected by the internal decay and to compare the obtained values with the carbon content of dead wood.

\section{CONCLUSIONS}

Our study approved the significant variation of stemwood basic density for different decay within grey alder stems. Accurate estimates of stem biomass in forest stands are crucial for calculating $\mathrm{C}$ budgets and fluxes under global climate change scenarios. However, to our knowledge, there are no studies dealing with density reduction caused by internal stem decay, combined with changes in wood $\mathrm{C}$ content through wood decomposition. The preliminary results of this study suggest that the decrease in wood density due to the internal decay must be taken into account in the stem biomass calculations that is an important step in reducing the uncertainty in the estimation of forest biomass and carbon stocks.

ACKNOWLEDGEMENT. Research was financed by the European Regional Development Fund (ERDF), postdoctoral research project No. 1.1.1.2/VIAA/4/20/687 "Reducing uncertainty in the calculation of forest stand biomass and carbon stock in Latvia".

\section{REFERENCES}

1. Aosaar J., Varik M., Lõhmus K., Uri V. 2011. Stemwood density in young grey alder (alnus incana (1) moench) and hybrid alder (alnus hybrida a. br.) stands growing on abandoned agricultural land. Baltic Forestry, Vol. 17(2), pp. 89-94.

2. Arhipova N., Gaitnieks T., Donis J., Stenlid J., Vasaitis R. 2011. Decay, yield loss and associated fungi in stands of grey alder (Alnus incana) in Latvia. Forestry, Vol. 84(4), pp. 337-348. https://doi.org/10.1093/forestry/cpr018

3. Brown S. 2002. Measuring carbon in forests: Current status and future challenges. In Environmental Pollution Vol. 116, pp. 363372. hhttps://doi.org/10.1016/S0269-7491(01)00212-3

4. Cienciala E., Černý M., Tatarinov F., Apltauer J., Exnerová Z. 2006. Biomass functions applicable to Scots pine. Trees - Structure and Function, Vol. 20(4), pp. 483-495. https://doi.org/10.1007/s00468-006-0064-4

5. CSB. 2019. Tree species in forests of Latvia. Available at https://data1.csb.gov.lv/pxweb/en/lauks/lauks_mezsaimn_plat_mez/MSG020.px/table/tableViewLayout1/ (In Latvian)

6. Hakkila P. 1971. Basic density, bark percentage and dry matter content of grey alder (Alnus incana). Communicationes Instituti Forestalis Fennia, Vol. 71(5), pp.7-33.

7. Houston Durrant T., Rigo D., Caudullo G. 2016. European Atlas of Forest Tree Species. (A. M. Jesus San-Miguel-Ayanz, Daniele de Rigo, Giovanni Caudullo, Tracy Houston Durrant, Ed.), European Atlas of Forest Tree Species. Publication Office of the European Union, Luxembourg. doi:10.2788/038466

8. Johansson T. 2005. Stem volume equations and basic density for grey alder and common alder in Sweden. Forestry, 78 (3), pp. 249-262. https://doi.org/10.1093/forestry/cpi023

9. Kärki T., Maltamo M., Eerikäinen K. 2000. Diameter distribution, stem volume and stem quality models for grey alder (Alnus incana) in eastern Finland. New Forests, Vol. 20, pp. 65-86. https://doi.org/10.1023/A:1006793616781

10. Köster K., Metslaid M., Engelhart J., Köster E. 2015. Dead wood basic density, and the concentration of carbon and nitrogen for main tree species in managed hemiboreal forests. Forest Ecology and Management, Vol. 354, pp. 35-42. https://doi.org/10.1016/j.foreco.2015.06.039.

11. Liepiņš J., Liepiņš K., Lazdiņš A. 2021. Equations for estimating the above- and belowground biomass of grey alder ( Alnus incana ( L .) Moench .) and common alder ( Alnus glutinosa L .) in Latvia. Scandinavian Journal of Forest Research, Vol. 36(5), pp. 389-400. https://doi.org/10.1080/02827581.2021.1937696

12. Neumann M., Moreno A., Mues V., Härkönen S., Mura M., Bouriaud O., Lang M., Achten W.M.J., Thivolle-Cazat A., Bronisz K., Merganič J., Decuyper M., Alberdi__., Astrup R.,_Mohrenn F., Hasenauera H. 2016. Comparison of carbon estimation methods for European forests. Forest Ecology and Management, Vol. 361, pp. 397-420. https://doi.org/10.1016/j.foreco.2015.11.016

13. Pan Y., Birdsey R., Fang, J., Houghton R., Kauppi, P. E., Kurz, W., Phillips O. L., Shvidenko A., LewisJosep S. L., Canadell G., Ciais P., Jackson R. B., Pacala S. W., McGuire A. D., Piao Sh., Rautiainen A., Sitch S., Hayes D. 2011. A large and persistent carbon sink in the world's forests. Science, 333, pp. 988-993. https://doi.org/10.1126/science.1201609

14. Repola J. 2009. Biomass equations for Scots pine and Norway spruce in Finland. Silva Fennica, Vol. 43(4), pp. $625-647$. https://doi.org/10.14214/sf.184

15. Rytter L., Ingerslev M., Kilpeläinen A., Torssonen P., Lazdina D., Löf M., Madsen P., Muiste P., Stener, L.-G. 2016. Increased 
forest biomass production in the Nordic and Baltic countries - A review on current and future opportunities. Silva Fennica, Vol. 50(5), pp. 1-33. https://doi.org/10.14214/sf.1660

16. Saranpää P. 2003. Wood density and growth. In: Barnett J.R., Jeronimidis G. (eds.). Wood quality and its biological basis. Blackwell Publishing Ltd, Oxford, UK. pp. 87-118.

17. Šenhofa S., Jaunslaviete I., Šņepsts G., Jansons J., Liepa L., Jansons A. 2020. Deadwood characteristics in mature and old-growth birch stands and their implications for carbon storage. Forests, Vol. 11(5), 536. https://doi.org/10.3390/f11050536

18. Stakènas V., Varnagirytė-Kabašinskienė I., Sirgedaitė-Šèžienė V., Armolaitis K., Araminienė V., Muraškienė M., Žemaitis P. 2020. Dead wood carbon density for the main tree species in the Lithuanian hemiboreal forest. European Journal of Forest Research, Vol. 139(6), pp. 1045-1055. https://doi.org/10.1007/s10342-020-01306-3 